\title{
Inferior Alveolar Nerve Injury after Mandibular Third Molar Extraction: a Literature Review
}

\author{
Rafael Sarikov ${ }^{1}$, Gintaras Juodzbalys ${ }^{1}$ \\ ${ }^{1}$ Department of Maxillofacial Surgery, Lithuanian University of Health Sciences, Kaunas, Lithuania.
}

\author{
Corresponding Author: \\ Rafael Sarikov \\ Ukmerges 5/17, LT 49410, Kaunas \\ Lithuania \\ Phone: +37067004458 \\ E-mail: rafael_sarikov@walla.com
}

\begin{abstract}
Objectives: The purpose of this study was to systematically review the comprehensive overview of literature data about injury to the inferior alveolar nerve after lower third molar extraction to discover the prevalence of injury, the risk factors, recovery rates, and alternative methods of treatment.

Material and Methods: Literature was selected through a search of PubMed electronic databases. Articles from January 2009 to June 2014 were searched. English language articles with a minimum of 6 months patient follow-up and injury analysis by patient's reporting, radiographic, and neurosensory testing were selected.

Results: In total, 84 literature sources were reviewed, and 14 of the most relevant articles that are suitable to the criteria were selected. Articles were analyzed on men and women. The influence of lower third molar extraction (especially impacted) on the inferior alveolar nerve was clearly seen.

Conclusions: The incidence of injury to the inferior alveolar nerve after lower third molar extraction was about $0.35-8.4 \%$. The injury of the inferior alveolar nerve can be predicted by various radiological signs. There are few risk factors that may increase the risk of injury to the nerve such as patients over the age of 24 years old, with horizontal impactions, and extraction by trainee surgeons. Recovery is preferable and permanent injury is very rare.
\end{abstract}

Keywords: fifth cranial nerve injury; inferior alveolar nerve; mandible; paresthesia; third molar; tooth extraction.

Accepted for publication: 22 November 2014

To cite this article:

Sarikov R, Juodzbalys G. Inferior Alveolar Nerve Injury after Mandibular Third Molar Extraction: a Literature Review.

J Oral Maxillofac Res 2014;5(4):e1

URL: http://www.ejomr.org/JOMR/archives/2014/4/e1/v5n4e1ht.pdf

doi: $10.5037 /$ jomr.2014.5401 


\section{INTRODUCTION}

Extraction of impacted or erupted mandibular third molars (M3s) is one of the most frequently performed dentoalveolar surgical procedures [1]. There are well-established indications [2] for removal of impacted M3s, and the controversies about prophylactic removal of asymptomatic M3s are based on evaluating the costs and risks of removal against the consequences of non-removal. The reasons for prophylactic surgery include the need to minimize the risk of disease (cysts and tumours), the reduction of the risk of mandibular angle fracture, increased difficulty of surgery with age, non-restorable caries or periodontal disease, and that M3s may be of less importance for mastication [2]. Within 4 - 8 weeks after surgery, $96 \%$ of inferior alveolar nerve (IAN) injuries recover [3], and the recovery rates are not influenced by gender and only slightly by age [4]. Some injuries may be permanent, lasting longer than 6 months, and with varying outcomes ranging from mild hypoesthesia to complete anaesthesia and neuropathic responses resulting in chronic pain [5]. The M3 is close to important structures such as the IAN, lingual nerve, and adjacent second molar. The lower it is, the more difficult it is to extract and more complications may occur during operation or postoperatively. Among them, injury of the IAN is of most concern for surgeons. Sometimes it is unavoidable and is most likely to lead to legal disputes between doctors and patients [6,7]. The risk of IAN injury (IANI) complication depends mainly on the position of the impacted tooth in relation to the mandibular canal (MC) before surgery. The IAN travels within the $\mathrm{MC}$ in the mandible, and is thus supported by the alveolus and the neurovascular bundle. Anatomically, the inferior alveolar vein is the most superior structure in the canal. When rotary instruments penetrate the canal, the bleeding will alert the surgeon that the superior aspect of the bony canal has been breached and the vein is injured. Nonsurgical removal of the M3 is unlikely to cause any damage to the nerve unless excessive force has been used. The radiographic position of the M3 in relationship to the MC has been shown to be useful in assessing the risk of damage to the IAN following extraction [8-10]. If the IAN is injured, unless it is displaced by bony fragments from the roof of the MC or displaced into the socket, it will remain within the canal and regenerate. The IAN neuropathy related to M3 surgery with a reported incidence of $1-20 \%$ temporary and 0 - $2 \%$ permanent [11]. IANI, and a subsequent sensory disturbance, may occur after direct or indirect trauma during M3 removal [12]. For example, it may result from compression of the nerve by root elevators and lead to blunt nerve trauma or elevated roots. The IAN may be damaged by rotating instruments used for the surgical procedure or after IAN regional anaesthetic block injections [13]. Clinical observation of the neurovascular bundle during surgery may notify the surgeon about an increased risk of postoperative IANI. Tay and Go [14] found that if an intact IAN bundle is observed during M3 surgery, this indicates an intimate relationship with the M3 and has a $20 \%$ risk of postoperative paresthesia, and with a $70 \%$ chance of recovery within one year. Damage to the nerve is also more likely when the tooth is completely impacted in the bone and/or the apices of the tooth extend into or below the level of the neurovascular bundle. IAN paresthesia occurs widely from $0.35 \%$ to $8.4 \%$ [15-17]. Consequently, the purpose of this study was to systematically review the comprehensive overview of literature data about injury to the inferior alveolar nerve after mandibular third molar extraction to find out the prevalence of injury, the risk factors, recovery rates, and alternative methods of treatment.

\section{MATERIAL AND METHODS Protocol and registration}

The review is registered in an international prospective register of systematic reviews 'PROSPERO' [18]. Registration number: CRD42014014231.

\section{Types of publication}

The review included studies on humans published in the English language. Letters, editorials, $\mathrm{PhD}$ theses, literature reviews, and abstracts were excluded.

\section{Types of studies}

The review included any published observational studies (cross-sectional surveys and case-control studies) and case series. Single case reports were excluded.

\section{Information sources}

The information source was the MEDLINE (PubMed) database.

\section{Population}

Studies of adult patients with performed M3 extractions were selected. Treatment had to be completed on healthy people without systemic diseases and immunological disorders. 


\section{Inferior alveolar nerve injury (IANI) definition}

Injury to the IAN means any sensory impairment of the nerve that occurs after surgical M3 extraction.

\section{Literature search strategy}

According to the PRISMA guidelines [19], an electronic search was conducted using MEDLINE (PubMed) to locate articles concerning IANI after M3 extraction. The keywords used for the search were: "INFERIOR ALVEOLAR NERVE INJURY THIRD MOLAR”, “INFERIOR ALVEOLAR NERVE THIRD MOLAR", "INFERIOR ALVEOLAR NERVE DAMAGE THIRD MOLAR", "INFERIOR ALVEOLAR NERVE PARESTHESIA THIRD MOLAR", "INFERIOR ALVEOLAR NERVE DYSESTHESIA
THIRD MOLAR", "PERMANENT INFERIOR ALVEOLAR NERVE INJURIES THIRD MOLAR". The search was restricted to English language articles published from January 2009 to June 2014. The search results revealed a high number of articles $(1,251)$; however, a significance number of the shown articles were not related to the topic and were excluded according the exclusion criteria. Selection and filtration were done in order to know which articles were more suitable for the research. In the beginning, the titles of the article were read, and if the title fit the general idea of the research, the abstract of the article was read. After the abstract reading and after ensuring that the article provided the necessary information for the research, the entire article was read. The bibliographies of the selected articles were also manually searched. Figure 1 illustrates the flow diagram of the comprehensive literature review.

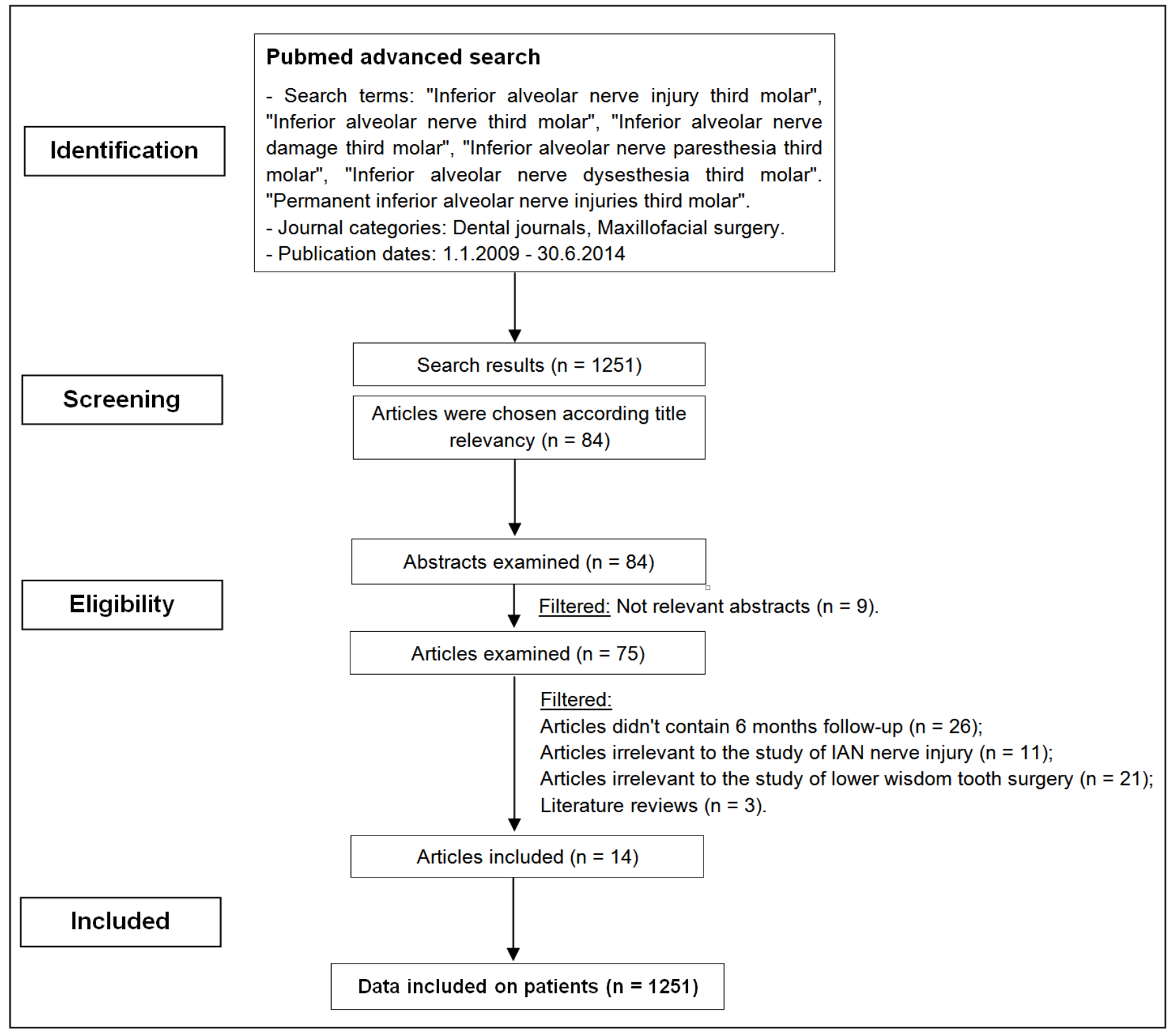

Figure 1. Flow diagram of studies selection according PRISMA guidelines. 


\section{Inclusion and exclusion criteria \\ Inclusion criteria for the selection}

- English language;

- Studies performed on humans who had no systemic diseases and immunological disorders;

- Articles must be limited to lower wisdom tooth surgery/alternative methods for surgery and IANI;

- Minimum follow-up of 6 months postoperation.

\section{Exclusion criteria for the selection}

- Unhealthy people with systemic diseases and immunological disorders;

- Patient follow-up shorter than 6 months;

- Articles irrelevant to the study of lower wisdom tooth surgery/alternative methods for surgery and IANI;

- Articles irrelevant according to the types of publications' exclusion.

\section{Article review and data extraction}

The search delivered 1,251 search results, from which 84 abstracts were reviewed (Figure 1). A total of 84 articles were ultimately reviewed in full. Preliminary exclusion was made by the title and its relevancy and later by abstract relevancy; finally, articles that did not meet the inclusion and exclusion criteria were filtered as follows:

- Articles didn't contain minimum follow-up of 6 months $(\mathrm{n}=26)$;

- Articles irrelevant to the study of IANI $(n=11)$;

- Articles irrelevant to the study of lower wisdom surgery $(n=21)$;
- Literature reviews $(\mathrm{n}=3)$;

- The data were included on 22,791 patients.

- In the present article, it will discuss the following IANI aspects:

- Risk factors:

- Radiographic techniques before M3 extraction;

- Alternative methods of M3 extraction;

- Recovery of IANI.

\section{Risk of bias across studies}

The risk of bias (e.g., lack of information, surgeries performed by single operator, postoperative neurosensory examination performed by single examiner, postoperative neurosensory testing not performed, specific age group, sex scission, and low objectives number) that can affect the cumulative evidence was assessed across the studies. The risks were indicated.

The Cochrane Collaboration's tool for assessing the risk of bias [20] was used to assess bias across the studies that can affect cumulative evidence.

\section{RESULTS}

A total of 14 studies were included in this review: 5 studies were related to risk factors associated with injury to the IAN, 5 studies were related to the influence of radiographic techniques before M3 extraction, 3 studies were related to alternative methods of M3 extraction, and 1 study was related to the recovery of IANI (Table 1).

Table 1. Description of studies included in the review

\begin{tabular}{|c|c|c|c|c|}
\hline Study & $\begin{array}{c}\text { Year of } \\
\text { publication }\end{array}$ & Diagnostic evidence & Follow-up & $\begin{array}{c}\text { Number of } \\
\text { patients treated }\end{array}$ \\
\hline \multicolumn{5}{|c|}{ Studies regarding risk factors associated with IANI } \\
\hline $\mathrm{Xu}$ et al. [22] & 2013 & Patient's reporting + Neurosensory testing & 6 months & 318 \\
\hline Kim et al. [를 & 2012 & Patient's reporting + Neurosensory testing + Radiographic & 2 years & 12,842 \\
\hline Jerjes et al. [47] & 2010 & Patient's reporting & 2 years & 3236 \\
\hline Kjolle et al. [48] & 2013 & Patient's reporting + Neurosensory testing & 5 years & 884 \\
\hline Guerrouani et al. [49] & 2013 & Patient's reporting & 6 months & 2112 \\
\hline \multicolumn{5}{|c|}{ Studies regarding the influence of radiographic techniques before M3 extraction } \\
\hline Smith [21] & 2013 & Patient's reporting + Neurosensory testing & 2 years & 1000 \\
\hline Neves et al. [33] & 2012 & Patient's reporting + Neurosensory testing & 6 months & 33 \\
\hline Nakayama et al. [35] & 2009 & Patient's reporting & Over 6 months & 1539 \\
\hline Hasegawa et al. [36] & 2013 & Patient's reporting + Neurosensory testing & 6 months & 295 \\
\hline Ghaeminia et al. [43] & 2009 & Patient's reporting + Neurosensory testing & 6 months & 40 \\
\hline \multicolumn{5}{|c|}{ Studies regarding alternative methods of mandibular M3 extraction } \\
\hline Landi et al. [ $\underline{50}]$ & 2010 & Patient's reporting + Radiographic & 2 years & 9 \\
\hline Wang et al. [ $\underline{\underline{52}}]$ & 2012 & Patient's reporting+ Radiographic & - & 40 \\
\hline Dolanmaz et al. [56] & 2009 & Patient's reporting + Radiographic & 4 years & 43 \\
\hline \multicolumn{5}{|c|}{ Study regarding recovery of IANI } \\
\hline Bhat et al. [43] & 2012 & Patient's reporting + Neurosensory testing & 6 months & 400 \\
\hline
\end{tabular}

IANI $=$ inferior alveolar nerve injury; M3 = third molar. 


\section{Study characteristics}

All 14 articles finally selected for the review were performed on humans and published in the English language with a description of their study, the methods used, the number of patients, as well as the preoperative and postoperative examination techniques. All studies published were in 2009 - 2013 years and included a various number of patients, from 9 (lowest) to 12,842 (highest) (Table 1) to ensure statistical validity.

All authors except one conducted a postoperative follow-up of a minimum of 6 months. The one exceptional study [13] was an alternative method for conventional surgical extraction (orthodontic technique), which included a preoperative follow-up until the tooth reached a safe position for extraction.

Preoperative radiographs were assessed before the M3 extraction in all studies, and it can be clearly seen that panoramic radiograph is the preoperative radiograph of choice (Table 2).

The main postoperative evaluation methods were: two-point discrimination, pin-prick, light touch, and with a light touch test in the top (Table 3 ).

\section{Reliability of studies}

The number of patients treated (Figure 2), the preoperative radiographs used (Table 2), the neurosensory evaluation methods used (Table 3), the follow-up period (Figure 3), and the bias within studies (Table 4) highly affects the reliability of a study. A comparison between the studies was completed.

\section{Risk of bias within studies}

Only 5 of the 14 studies fulfilled the expected markers of validity. The risk of bias that was indicated within other studies and presented as a lack of information value was grouped as followed: treatment performed by a single operator, post-treatment neurosensory testing performed by a single examiner, postoperative neurosensory testing not performed, specific age group treated, sex scission, and low objectives number (Table 4).

\section{Anatomic relationship and incidence of IAN neurosensory impairment}

Neurosensory impairment is a common complication of extraction of impacted $\mathrm{M} 3 \mathrm{~s}$, and the incidence ranges from $0.35 \%$ to $8.4 \%[15-17,21]$. In 2013 , Smith [21] presented a clinical study on 1,000 patients, removing 1,589 impacted M3 teeth. Of the 1,589 M3 teeth extracted, 466 (29\%) demonstrated a distant relationship of their apices to the MC, $869(55 \%)$ were close to the canal, and only $254(16 \%)$ were deemed to be intimate to the canal by radiographic evidences (Table 5). In postoperation, 39 patients $(3.9 \%)$ reported neurosensory disturbance over the distribution of the IAN nerve in 40 extractions. Seven patients $(0.7 \%)$ sustained permanent sensory loss. The incidence of IAN neurosensory deficit was highest with horizontal impaction (4.7\%) and lowest when the teeth were vertically impacted $(0.9 \%)$.

Table 2. Preoperative radiographs used in the studies

\begin{tabular}{|c|c|}
\hline Author & Preoperative radiograph used \\
\hline Smith [21] & OPG \\
\hline $\mathrm{Xu}$ et al. [22] & $\mathrm{OPG}+\mathrm{CBCT}$ \\
\hline Kim et al. [24] & OPG \\
\hline Neves et al. [33] & MDCT \\
\hline Nakayama et al. [35] & $\mathrm{OPG}+\mathrm{CT}$ \\
\hline Hesagawa et al. [흐] & $\mathrm{OPG}+\mathrm{CT}$ \\
\hline Ghaminia et al. [녀] & $\mathrm{OPG}+\mathrm{CT}$ \\
\hline Bhat and Cariappa [44] & Not indicated \\
\hline Jerjes et al. [47] & OPG \\
\hline Kjolle et al. [48] & OPG \\
\hline Guerruani et al. [49] & OPG \\
\hline Landi et al. [ $\underline{50}]$ & $\mathrm{OPG}+\mathrm{CT}+$ Periapical \\
\hline Wang et al. [ $\underline{52}]$ & $\mathrm{OPG}+\mathrm{CT}$ \\
\hline Dolanmaz et al. [56] & OPG \\
\hline
\end{tabular}

OPG = orthopantomography; $\mathrm{CT}=$ computed tomography; $\mathrm{CBCT}=$ cone-beam computed tomography; $\mathrm{MDCT}=$ multi-detector computed tomography.

Table 3. Postoperative neurosensory evaluation methods used

\begin{tabular}{|c|c|c|c|c|c|c|}
\hline & Pin-prick & $\begin{array}{c}\text { 2-point } \\
\text { discrimination }\end{array}$ & $\begin{array}{c}\text { Sharp blunt } \\
\text { discrimination }\end{array}$ & $\begin{array}{c}\text { Light touch/ } \\
\text { contact detection }\end{array}$ & $\begin{array}{c}\text { Thermal } \\
\text { testing }\end{array}$ & $\begin{array}{c}\text { Brush stroke } \\
\text { direction }\end{array}$ \\
\hline Smith [21] & + & + & & + & & \\
\hline Kim et al. [르] & + & + & & + & & \\
\hline Neves et al. [33] & & & + & + & & \\
\hline Hasegawa et al. [하] & + & & & + & & \\
\hline Ghaeminia et al. [43] & & & & + & & \\
\hline Bhat et al. [44] & + & + & & + & + & + \\
\hline Kjølle et al. [48] & & + & + & + & & \\
\hline
\end{tabular}




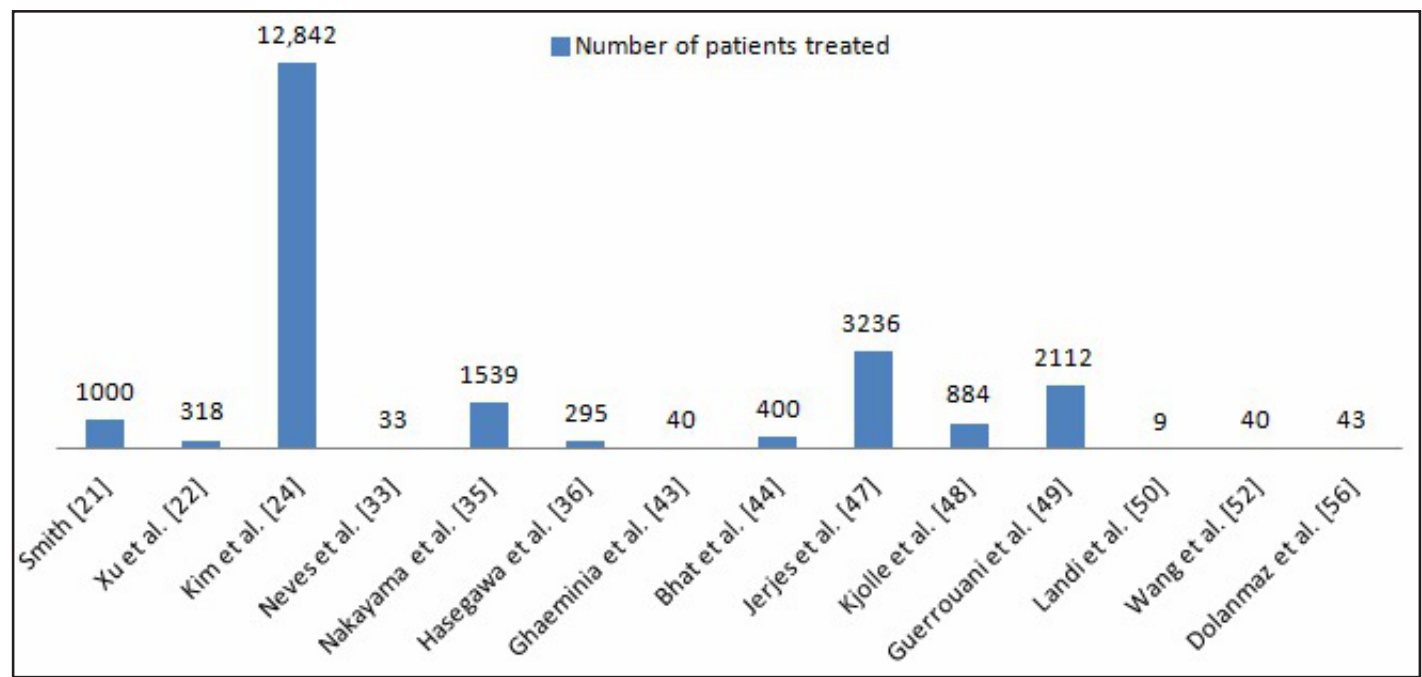

Figure 2. Number of patients treated.

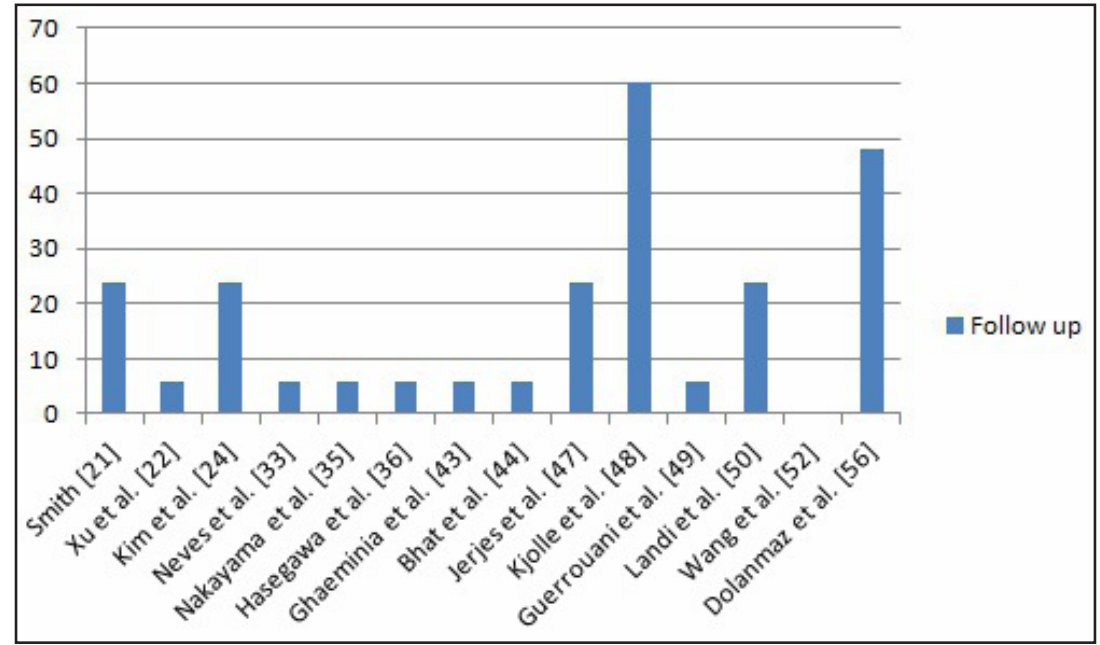

Figure 3. Postoperative follow-up period (months).

Table 4. Assessment of the risk of bias

\begin{tabular}{|c|c|c|c|c|c|c|}
\hline & $\begin{array}{c}\text { Treatment } \\
\text { performed by } \\
\text { single operator }\end{array}$ & $\begin{array}{l}\text { Post-treatment neurosensory } \\
\text { testing (NST) performed } \\
\text { by single examiner }\end{array}$ & $\begin{array}{l}\text { Post-treatment } \\
\text { NST not } \\
\text { performed }\end{array}$ & $\begin{array}{l}\text { Specific } \\
\text { age group } \\
\text { treated }\end{array}$ & Sex scission & $\begin{array}{c}\text { Low } \\
\text { objectives } \\
\text { number }\end{array}$ \\
\hline Smith [21] & + & + & - & - & - & - \\
\hline Nakayama et al. [35] & & & + & & & \\
\hline Ghaeminia et al. [ $\underline{\underline{43}}]$ & - & + & - & - & - & - \\
\hline Bhat and Cariappa [44] & + & + & - & - & - & - \\
\hline Jerjes et al. [47] & & & + & & & \\
\hline Guerrouani et al. [49] & & & + & & & \\
\hline Landi et al. [50] & & - & + & - & - & $+(n=9)$ \\
\hline Wang et al. [52] & + & - & + & $+(20-30)$ & + (Females only) & - \\
\hline Dolanmaz et al. [ $\underline{56}]$ & & & + & & & \\
\hline
\end{tabular}

Table 5. Proximity of the root's apices to the mandibular canal (MC)

\begin{tabular}{l|l}
\hline Proximity to the MC & \multicolumn{1}{c}{ Description } \\
\hline Distant from the canal & There is a radiologic separation of $>1 \mathrm{~mm}$ between the tips of the roots of the third molar and the MC. \\
\hline Close to the canal & There is unchanged superimposition of the root apices over the MC. \\
& $\begin{array}{l}\text { The tips of the roots are considered to be intimate to the MC when } \geq 1 \text { of the following 3 criteria are met: } \\
\text { Intimate to the canal }\end{array}$ \\
& 1. Diversion of the MC; \\
& 2. Darkening of the root; \\
& 3. $\quad$ Deflected root apices. \\
\hline
\end{tabular}


However, the difference between each type of impaction is not statistically significant $(\mathrm{P}>0.01)$. The overall incidence of IAN nerve damage was $2.5 \%$ per tooth removal. The lowest incidences were seen when the nerve was either "distant" $(0.8 \%)$ or "close" $(0.9 \%)$, and highest when the nerve was classed as "intimate" (11\%). The difference between the "distant" and "intimate" groups was statistically significant $(\mathrm{P}<0.01)$. The difference between the "close" and "intimate" groups was also statistically different $(\mathrm{P}<0.01)$. Yet, this study has limitations because the preoperative radiologic assessment, as well as the postoperative neurologic testing, was performed by the same clinician, thereby potentially introducing bias to the results.

In addition, $\mathrm{Xu}$ et al. [22] studied 537 impacted M3s in 318 consecutive patients. Most of them were mesioangular and vertical impactions. Horizontal impacted teeth were in the minority. A total of 272 were above the MC, 86 on the buccal side, 172 on the lingual side, and the canal was between the roots in 7 teeth. By the results shown (Table 6), we can see that the highest IANI rates are when the roots' tips are buccaly to the MC.

\section{Risk factors of IAN impairment \\ Radiological factors}

Orthopantomography

Orthopantomography (panoramic radiography) is the radiologic investigation of choice before M3 surgery. The criteria for injury are identifiable on this radiograph, but like other conventional radiographs, it is unable to give complete information in 3 dimensions [23]. In a study performed by Kim et al. [24], on a total of 12,842 patients who underwent extraction of the M3, univariate logistic regression analysis showed that the significant risk factors for neurosensory deficits according to the panoramic radiograph were the deflection of the root, narrowing of the root, diversion of the canal, and narrowing of the canal $(\mathrm{P}<0.5)$. In contrast, a multivariate logistic regression analysis revealed that the significant risk factors were a darkening of the root, deflection of the root, narrowing of the root, dark and bifid apexes of the root, and narrowing of the MC.
The narrowing of the root was the most significant type of superimposition, followed by dark and bifid apexes of the root. However, the presence or absence of these radiographic signs does not always determine the possibility IANI, indicating that the panoramic radiograph does not have high diagnostic accuracy in the assessment of risk in surgical extractions of lower M3s $[25,26]$.

\section{Computed tomography (CT)}

When the radiological marker on the panoramic radiograph indicates there is a close relationship between the M3 and the MC, additional investigation using computed tomography (CT) may be recommended to verify the relationship in a threedimensional view [27-29]. The drawbacks of CT are the higher radiation dose and increased financial costs compared with panoramic imaging. Cone beam computed tomography (CBCT) has been introduced to improve conventional $\mathrm{CT}$ because it reduces the radiation dose, offers high spatial resolution, and decreases costs [30]. CBCT provides better image quality of teeth and their surrounding structures compared with conventional CT [31,32]. By the results in a study comprised by Neves et al. [33], in all 14 cases where IAN was exposed during surgery, the preoperative assessment by multidetector computed tomography (MDCT) images classified the relationship between the roots of the $\mathrm{M} 3 \mathrm{~s}$ and the $\mathrm{MC}$ as at-risk (the tooth roots invade and restrict the MC space). There was a statistically significant relationship between IAN exposure and the relationship between the roots of the M3s and the MC $(\mathrm{P}=0.015)$. MDCT is considered one of the most valuable imaging modalities for preoperative procedures because it allows the acquisition of fast, reliable, and reproducible images. Each slice can be viewed individually in the 3 planes (axial, coronal, and sagittal), and the overlapping of surrounding anatomical structures can be eliminated. Other advantages, such as the possibility of threedimensional reconstruction of the evaluated structure and optimal contrast resolution, allow differentiation between tissues so that the obtained information is utilized more efficiently compared with conventional

Table 6. Inferior alveolar nerve (IAN) injury and recovery according to anatomic relationship of the roots' tips in relation to the mandibular canal (MC)

\begin{tabular}{c|c|c|c|c}
\hline Position of the roots in relation the MC & Above the canal & Buccal side & Lingual side & Canal between the roots \\
\hline IAN injury incidence & $9 / 272(3.3 \%)$ & $16 / 86(18.6 \%)$ & $8 / 172(4.6 \%)$ & $0 / 7(0 \%)$ \\
\hline P value & 0.006 & $<0.0001$ & 0.32 & - \\
\hline IAN recovery & 23 healed within a week, and 10 healed within 6 months. No permanent injury. \\
\hline
\end{tabular}


radiographic techniques [34]. Nakayama et al. [35] performed extractions of $1,853 \mathrm{M} 3$ teeth in 1,539 patients in their study. Among them, dental CT was performed on $53 \mathrm{M} 3 \mathrm{~s}$ in 47 patients because their M3s were determined to be extremely close to the IAN on panoramic radiograph. The M3s were judged to make contact with the MC on dental three-dimensional images in 35 cases $(66 \%)$. IANI occurred in 8 cases $(15 \%)$. The mental region skin sensation of 4 cases returned within 3 months. However, in the other 4 cases, symptoms of IANI continued over 6 months. When the relation between dental CT image and IANI was investigated, all 8 cases of IANI were those in which the contact of the M3 with the MC was seen on dental three-dimensional CT images. No IANI occurred in cases without contact between the molar and the canal. Hasegawa et al. [36] published a study in 2013 in which $440 \mathrm{M} 3 \mathrm{~s}$ were removed. Of the 440 teeth, according to CT scanning, $146(33.2 \%)$ IANs were in the buccal position, $195(44.3 \%)$ were in the inferior position, $95(21.6 \%)$ were lingual, and 4 $(0.9 \%)$ were in the inter-radicular position. The ratio of IANI in the extraction group with a lingual position between the roots was significantly higher $(\mathrm{P}<0.05)$ than that in the group with other positions. Through the logistic regression model and forward stepwise algorithms, they determined that the close relationship of the roots to the IAN on CT examination is a significant variable in predicting an injury after M3 extraction $(\mathrm{P}<0.000)$.

\section{Surgeon experience}

The prevalence of IANI is also dependent on the surgeon experience and the methods used. The results published by Hasegawa et al. [36] have shown that IANI developed in 3 of $71(4.2 \%)$ teeth in patients treated by the surgeons with $1-4$ years of experience, in 14 of $175(8 \%)$ teeth in the group treated by surgeons with 5 - 9 years of experience, and 11 of $194(5.7 \%)$ teeth in the group of patients treated by surgeons with more than 10 years of experience. The incidence of IANI after extraction by surgeons with 5 - 9 years of experience was the highest in the 3 groups. However, there was no significant difference in the incidence based on surgeon seniority $(\mathrm{P}>0.01)$.

\section{Additional factors}

The additional factors implicated in IANI include the age of the patient and the local blood supply. The reasons for this might be that the healing ability decreases with an increasing age and that more bone is usually removed owing to completely formed roots or increased bone mineralization [37]. Accordingly, Blondeau and Daniel [38] recommended that prophylactic M3 extraction should be avoided in patients aged 24 years or older because of a high possibility of complications such as permanent neurosensory deficits, infection, and alveolitis.

\section{Evaluation of sensory impairment after extraction}

In order to evaluate nerve dysfunction, it is important to use objective testing rather than to simply ask a patient to subjectively report neuropathic changes. Neurosensory disorders can be measured through various test levels (Table 7).

A study performed by Ghaeminia et al. [43] included extraction of $53 \mathrm{M} 3 \mathrm{~s}$ from 40 patients with an increased risk of IANI. Neurosensory disturbances of

Table 7. Neurosensory evaluation tests

\begin{tabular}{|c|c|c|c|c|c|c|}
\hline & \multicolumn{2}{|c|}{ Level A tests } & Level B test & \multicolumn{3}{|c|}{ Level C tests } \\
\hline 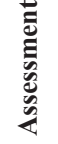 & \multicolumn{2}{|c|}{$\begin{array}{l}\text { This test is used to determine the response of the slowly } \\
\text { adapting larger myelinated fibbers (A-a) }\end{array}$} & $\begin{array}{l}\text { Assesses the } \\
\text { quickly adapting } \\
\text { large myelinated } \\
\text { (A-a) fibbers }\end{array}$ & \multicolumn{3}{|c|}{ These tests assess the small myelinated A-d and C fibbers } \\
\hline 象导 & $\begin{array}{l}\text { Two-point discrimination test } \\
{[[\underline{39}, \underline{40}]}\end{array}$ & $\begin{array}{l}\text { Brush stroke direction } \\
\qquad[\underline{39}, \underline{40}]\end{array}$ & $\begin{array}{l}\text { Contact detection/ } \\
\text { light touch }[\underline{39}]\end{array}$ & $\begin{array}{l}\text { Thermal testing } \\
{[\underline{40}]}\end{array}$ & $\begin{array}{l}\text { Sharp blunt } \\
\text { discrimination }[\underline{41}]\end{array}$ & $\begin{array}{l}\text { Pin prick test } \\
{[\underline{42}]}\end{array}$ \\
\hline 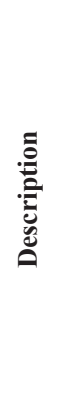 & $\begin{array}{l}\text { Two pointed, but not sharp, } \\
\text { tips of a calliper touch the } \\
\text { skin simultaneously with light } \\
\text { pressure while the patient's eyes } \\
\text { are closed. The separation of the } \\
\text { two points are gradually reduced } \\
\text { from } 20 \mathrm{~mm} \text { at the chin and } 10 \\
\text { mm at the lips to the moment } \\
\text { where the patient can feel } \\
\text { one point only. The minimum } \\
\text { separation at which two points } \\
\text { can be report is recorded. }\end{array}$ & $\begin{array}{l}\text { The sensory modalities } \\
\text { for these receptors are } \\
\text { vibration, touch and } \\
\text { flutter. Moving stimuli } \\
\text { is delivered with a soft } \\
\text { brush at a fairly constant } \\
\text { velocity }(2-3 \mathrm{~cm} / \mathrm{s}) \text {. } \\
\text { Ten, two interval forced } \\
\text { choice trials are then } \\
\text { delivered to verify that } \\
\text { the direction of motion } \\
\text { is identified correctly. }\end{array}$ & $\begin{array}{l}\text { The contact } \\
\text { detection threshold, } \\
\text { the minimum force } \\
\text { of contact against } \\
\text { the skin that is } \\
\text { felt, is measured } \\
\text { with the use of } \\
\text { a monofilament } \\
\text { mounted onto end } \\
\text { of a plastic handle. }\end{array}$ & $\begin{array}{l}\text { Perception of warmth } \\
\text { is attributed to the } \\
\text { integrity of A-d fibbers } \\
\text { and cold to C fibbers. } \\
\text { Two small glass tubes } \\
\text { containing water at } \\
50^{\circ} \mathrm{C} \text { (warm) and } 15^{\circ} \mathrm{C} \\
\text { (cold) were used. The } \\
\text { report of each stimulus } \\
\text { i.e. cold versus hot is } \\
\text { record. }\end{array}$ & $\begin{array}{l}\text { This is done by touching } \\
\text { the test area randomly } \\
\text { with a sharp or a blunt } \\
\text { head of the mechanical } \\
\text { probe. A rubber stopper } \\
\text { is centred at the end } \\
\text { of the dental probe so } \\
\text { that when the tip is } \\
\text { pressed to the skin, a } \\
\text { constant degree of skin } \\
\text { indentation was cause. }\end{array}$ & $\begin{array}{l}\text { Consisted of } \\
\text { repeating ten } \\
\text { touches with an } \\
\text { explorer tip on } \\
\text { the chin skin and } \\
\text { perform how } \\
\text { many times the } \\
\text { patient accused } \\
\text { the contact. }\end{array}$ \\
\hline
\end{tabular}


the lip and chin were assessed by measuring the function of the IAN with light touch sensation. The contralateral halves of the lip and chin were taken as a control site. The area with impaired sensation was drawn on the skin and recorded photographically. The patients with altered sensation returned 3 and 6 months postoperatively and their recovery pattern was noted. Neurosensory disturbances of the lip and chin were assessed by measuring the function of the IAN with light touch sensation. Based on the neurosensory testing, temporary IANI occurred in 5 patients $(9 \%)$. Altered sensations lasting longer than 6 months were scored as permanent IANI (3 patients [6\%]). In this study, a bias exists because the neurosensory testing of all patients was carried out by only one investigator, which may influence the results' reliability. In addition, in a study conducted by Bhat and Cariappa [44] a total of $400 \mathrm{M} 3 \mathrm{~s}$ were extracted. Out of 400, only one patient presented with IANI $(0.25 \%)$. Levels A and B tests (two-point discrimination, brush-stroke direction, and contact detection) were altered. In these tests, the IAN did not show any signs of recovery by 6 months. Level C tests (pin-prick test and sharp blunt detection) showed that the nerve had recovered completely by 2 months, which may highly doubt the reliability of level A and B tests, although limitation in this study exists because all cases were examined by one examiner preoperatively and postoperatively.

\section{Recovery rates of the IAN after injury}

In most cases, IAN paresthesia is temporary and recovers within 6 months [45], and the risk of permanent injury, in which sensory impairment lasts longer than 6 months, is less than 1\% [46]. A study published in 2010 by Jerjes et al. [47] included 3,236 patients who underwent surgical removal of impacted M3s. Over three-quarters $(2531 / 3236,78.2 \%)$ of the teeth were close to the MC $(<2 \mathrm{~mm})$, when assessed on the two-dimensional orthopantomograph. After one month, 48 patients experienced IAN paresthesia. The prevalence of paresthesia at 6 months had only slightly reduced to 45. At 18 to 24 months postoperatively, 20 patients still exhibited IAN paresthesia. In addition, in a study published in 2013 by Kjolle et al. [48], of the total $1,220 \mathrm{M} 3 \mathrm{~s}$ removed from 864 patients, 10 reported hypesthesia, anaesthesia, paresthesia, or dysesthesia postoperatively. After 3 - 4 months, the patients aged 29 years or younger had recovered fully. Three of the 8 patients older than 30 years had also full subjective recovery of the IAN after $1-17$ months. The results showed that after 6 months, recovery seemed to be slight, and confirmed that permanent IAN dysfunction is more frequent after M3 removal in patients older than 30 years $(\mathrm{P}<0.007)$.

\section{Methods of treatment \\ Surgical extraction}

Surgical treatment for an impacted M3 is the conventional and most popular method used. The surgical treatment contains few stages of treatment: anaesthesia (local/general), flap elevation, if necessary root sectioning and bone removal, elevation/luxation of the tooth, later socket irrigation, and a suture to close the wound. A study published in 2013 by Guerrouani et al. [49] included surgical extraction of $7,659 \mathrm{M} 3 \mathrm{~s}$ for 2,112 patients. All surgeries were carried out with the same surgical technique: sulcular incision and flap raising of the first or second molar with subsequent discharge. Bone removal, dental cutting, and separation (cracking) were carried out using a single bur in tungsten carbide; the sutures used were Vicryl Rapide 3/0. A sensory labiomental dysesthesia (anaesthesia, hypoesthesia, or paresthesia) was reported in 9 cases $(0.4 \%)$, always in relation with the hemilateral tooth section. Partial regression was experienced by the patient after 3 months in 6 cases, while in 3 other cases, it did not seem to improve during the same period. Methods of surgical treatment are wide and every surgeon uses different methods (e.g. anaesthesia, flaps, bone-removal, tooth-sectioning, different approaches, and sutures) according to his experience and results.

\section{Novel surgical technique}

Landi et al. [50] used a new surgical approach that was proposed and accepted by the patients. This approach consisted of the surgical removal of the mesial portion of the anatomic crown to create adequate space for mesial M3 migration. After the migration of the M3 had taken place, the extraction could then be accomplished in a second surgical session minimizing neurological risks. This technique has been also described in another article [51]. Nine consecutive patients required the extraction of 10 horizontally or mesioangular impacted M3s. In all cases, the M3 was in contact with the IAN with a high risk of nerve injury. In all cases, healing was uneventful. Three to 4 months after the surgery, all M3s moved forward and reached the distal aspect of the second molars. In 8 cases, radiographic evidence demonstrated clearance between the roots and the IAN so that a risk-free extraction could be scheduled. In 2 cases, the degree of migration was judged 
Table 8. Comparison between orthodontic and surgical extraction methods

\begin{tabular}{l|c|c}
\hline & $\begin{array}{c}\text { Group 1 } \\
\text { (orthodontic method) }\end{array}$ & $\begin{array}{c}\text { Group 2 } \\
\text { (surgical method) }\end{array}$ \\
\hline Number of patients & 20 & 20 \\
\hline Number of IANI cases & 0 & 5 \\
\hline Patients' complaint & No complaints & Transient lower lip numb \\
\hline Swelling & Minimal & Different degrees of swelling \\
\hline Postoperative medications & - & $\begin{array}{c}\text { Application of steroids and nerve nutrition medications; } \\
\text { Intravenous antibiotics for at least 3 days }\end{array}$ \\
\hline Recovery & - & 1 week postoperation \\
\hline
\end{tabular}

IANI $=$ inferior alveolar nerve injury.

inadequate to extract the teeth safely; therefore, a second surgical section was required to gain further space for mesial migration. This study does have limitations because the number of patients is relatively low $(\mathrm{n}=9)$, which may affect the reliability of the study and introduce bias to the results.

\section{Orthodontic extraction technique}

Since there are patients who are at a high risk for operation, occurrence of IANI is relatively high, and the orthodontic extraction technique is recommended to the patients to reduce the postoperative complications. This technique needs an orthodontist to design and put a special bar on the tooth to control the direction of traction. It also needs a long time of traction from 6 to 12 months, especially for medially inclined and horizontal teeth to be away from the IAN. Patients also need frequent followups to unite, reshape, and reactivate the cantilever every 4 to 6 weeks before the tooth is ready to be extracted. Of the 2 methods of this technique, one uses orthodontic brackets and hooks on the maxillary molars. The other method includes placing bone mini screws between them [52]. A study published in 2012 by Wang et al. [52] included 40 patients who were divided into 2 groups. In one group, 20 patients agreed to the orthodontic extraction technique, and in the second group, the other 20 did not want this technique and had the tooth removed directly because of various reasons including treatment time, etc. Postoperative results were compared between the 2 groups, and it can be clearly seen that the orthodontic extraction technique is very efficient $(\mathrm{P}<0.01)$ although time consuming (Table 8). The results in this study contain a bias, which is that the treatment was performed only on females, on a specific age group of 20 - 30 years old, and in addition, the extractions in the second group were done by the same surgeon.
Table 9. Total amount of movement of root remnants along time

\begin{tabular}{c|c|c|c}
\hline Time & $\begin{array}{c}\text { Range of } \\
\text { movement } \\
\text { (mm) }\end{array}$ & $\begin{array}{c}\text { Mean amount of } \\
\text { movement } \\
(\mathbf{m m})\end{array}$ & P value \\
\hline 6 months & $2-4.8$ & 3.4 & \multirow{2}{*}{$<0.01$} \\
\hline 12 months & $0.1-0.9$ & 3.8 & \\
\hline 24 months & $0-0.3$ & 4 & \\
\hline
\end{tabular}

\section{Coronectomy technique}

Another alternative found to overcome the risk of IANI is intentional coronectomy. Clinicians [53-55] use coronectomy to protect the IAN for mesioangular and vertical bony impacted M3s. The disadvantage of a coronectomy is the possible need for a second operation to remove the root, a late infection of the retained roots, and a high complication rate of unsatisfactory healing [ $\underline{54-56}$. But it could be an optimal solution for tooth ankyloses, where the orthodontic extraction technique is ineffective [55]. Not all M3 teeth are suitable for coronectomy. Teeth with acute infection and mobile teeth should be excluded because root remnants of those teeth may act like foreign bodies. In addition, teeth that are horizontally impacted along the course of the MC may be unsuitable because the sectioning of a tooth could endanger the nerve [56]. Dolanmaz et al. [57] used coronectomy in 43 patients who needed removal of their M3, and whose root apices were very close to the MC. In total, 47 teeth underwent coronectomy, and the total amount of movement of the root remnants is presented (Table 9). All patients were invited to return for appointments at 6,12 , and 24 months for clinical and radiographic assessment of the retained root fragments. The root remnants were clinically examined for infection and the amount of movement was measured. None of the patients reported any problems associated with the root fragments. In all cases, the radiographs revealed that the root fragments showed various amounts of movement farther away 
from the MC. None of the retained roots required a second operation.

\section{DISCUSSION}

The purpose of this review was to discover the relation between extractions of the mandibular wisdom tooth to the injury of the IAN, as well as to find out the prevalence of injury, the risk factors, recovery rates, and alternative methods of treatment.

The mandibular nerve is the third and the most inferior branch of the trigeminal nerve or the fifth cranial nerve. The lower branch is called the mandibular nerve. The nerve enters the mandible through the mandibular foramen on the medial surface of the ascending mandibular ramus. After passing through the mandibular foramen, the nerve is called the IAN. In the molar region, the IAN divides into the mental and mandibular incisal nerves [57].

IANI is a characteristic complication following the removal of an impacted M3 [58-60]. Although the incidence of such a complication is relatively low, its frequency increases as the roots of the impacted tooth move closer to the IAN [60]. To reduce the neurological risks, several strategies may be used. Wang et al. [51], in their study, used the orthodontic extraction technique, and through their results, it is clearly seen that this method is preferable over the surgical method in reducing the risk of paresthesia, yet it is time consuming and expensive and may not be tolerable for the patient. Dolanmaz et al. [56], in their study, used coronectomy in patients whose root apices were very close to the MC. By the results published, in all cases, the radiographs revealed that the root fragments showed various amounts of movement farther away from the MC, and none of the retained roots required a second operation, which significantly proves the efficiency of this technique. The novel approach presented by Landy et al. [50] aims to provide adequate space distal to the second molar to allow spontaneous M3 eruption to move the roots away from the neurovascular bundle. This novel technique aims to exploit this potential eruption by providing space distal to the second molar by removing a portion of the M3 crown. The amount of sectioning should take into account several factors: 1) tooth position and angulations; 2) the degree of mesial shift desired to move the roots away from the nerve; and 3) pulp chamber anatomy. Although a generous sectioning is desirable, every effort should be made, at least during the first odontectomy, to not interfere with tooth vitality. In the case of accidental pulp exposure, a pulpotomy may be performed to minimize the risk of postoperative pain and discomfort. Evidence suggests that in young adults, $26 \%$ to $35 \%$ of unerupted mandibular M3s may change position over time and reach the occlusal plane $[\underline{61,62]}$. Predicting IANI before surgical intervention is a common desire for the surgeon and the patient. Panoramic radiography is the supplementary examination initially requested to assess impacted $\mathrm{M} 3 \mathrm{~s}$ and estimate the risk of damage to the IAN. When specific signs are detected, $\mathrm{CT}$ is recommended for three-dimensional evaluation [63] to assess the relationship of the M3s with anatomical structures, especially the $\mathrm{MC}$, and provide a higher operative safety [64-66].

The risk factors of postoperative IANI include the surgeon's experience, the age and sex of the patient, the degree of operative tissue damage, surgical instruments, and postoperative oedema. The most important factor, however, is the anatomical relation between the impacted M3 and the MC $[47, \underline{67}, \underline{68]}$. By the results shown by Kim et al. [23], age, impaction depth, and the 5 radiographic superimposition signs: darkening of the roots, deflection of the roots, narrowing of the roots, dark and bifid apex of the roots, and narrowing of the canal were significantly associated with neurosensory deficits of the IAN after M3 extraction. The number of subjects in this study was significantly big (12,842 patients), increasing the reliability of their results. In contrast, some authors $[\underline{50}, \underline{52}, \underline{56}]$ didn't perform neurosensory testing in order to evaluate IANI, only the X-ray examination, while other authors $[\underline{35}, \underline{47}, \underline{49}]$ didn't perform any examination at all, rather than simply asking the patients about their sensory feelings, which may bring uncertainty to the reliability of their results.

The age and gender of the patients should be taken into account because it is well documented for all types of nerve injuries that both factors are at higher risk of neurosensory deficits [37,69-71]. The surgeons have to make a preliminary neurosensory examination of IAN function before M3 extraction in order to determine whether there is pre-existing altered sensation [71].

In most cases, complete recovery of IANI occurs 6 to 8 weeks after the trauma, although it may take up to 24 months. If paraesthesia is not completely resolved within about 2 months, the probability of a permanent deficit increases significantly [72]. In accordance with the findings of the study published by Kim et al. [23], IANI after M3 extraction is usually not permanent but continues for a few months and shows spontaneous recovery in the first 6 months. 


\section{CONCLUSIONS}

Inferior alveolar nerve paresthesia occurs widely from $0.35 \%$ to $8.4 \%$. Although these figures are relatively low, they are still of great significance for both patients and clinicians. Sometimes the injuries are unavoidable and may have legal disputes between doctors and patients. All patients must be warned of the risks of mandibular third molar surgery, including possible damage to the inferior alveolar nerve, and informed consent must be obtained before the procedure. With regard to the inferior alveolar nerve, the factors associated with a significantly higher incidence of paresthesia includes patients over the age of 24 years old, with horizontal impactions, close radiographic proximity to the mandibular canal, and treatment by inexperienced surgeons. In order to reduce the neurological risks, alternative strategies might be used like coronectomy and orthodontic extraction techniques.

It has been found that injury to the inferior alveolar nerve is usually not permanent and has a good likelihood of regenerating over time, and most of the injuries are healed after 6 months.

\section{ACKNOWLEDGMENTS AND DISCLOSURE STATEMENTS}

The authors report no conflicts of interest related to this study.

\section{REFERENCES}

1. Grossi GB, Maiorana C, Garramone RA, Borgonovo A, Creminelli L, Santoro F. Assessing postoperative discomfort after third molar surgery: a prospective study. J Oral Maxillofac Surg. 2007 May;65(5):901-17. [Medline: 17448840] [doi: 10.1016/j.joms.2005.12.046]

2. NIH consensus development conference for removal of third molars. J Oral Surg. 1980 Mar;38(3):235-6. [Medline: $\underline{6101618]}$

3. Alling CC 3rd. Dysesthesia of the lingual and inferior alveolar nerves following third molar surgery. J Oral Maxillofac Surg. 1986 Jun;44(6):454-7. [Medline: 3457927] [doi: 10.1016/S0278-2391(86)80010-6]

4. Hillerup S, Stoltze K. Lingual nerve injury in third molar surgery I. Observations on recovery of sensation with spontaneous healing. Int J Oral Maxillofac Surg. 2007 Oct;36(10):884-9. Epub 2007 Sep 4. [Medline: 17766086] [doi: 10.1016/j.ijom.2007.06.004]

5. Hillerup S. Iatrogenic injury to oral branches of the trigeminal nerve: records of 449 cases. Clin Oral Investig. 2007 Jun;11(2):133-42. Epub 2006 Dec 22. [Medline: 17186310] [doi: 10.1007/s00784-006-0089-5]

6. Alessandri Bonetti G, Bendandi M, Laino L, Checchi V, Checchi L. Orthodontic extraction: riskless extraction of impacted lower third molars close to the mandibular canal. J Oral Maxillofac Surg. 2007 Dec;65(12):2580-6. [Medline: 18022488] [doi: 10.1016/j.joms.2007.06.686]

7. Susarla SM, Blaeser BF, Magalnick D. Third molar surgery and associated complications. Oral Maxillofac Surg Clin North Am. 2003 May;15(2):177-86. [Medline: 18088673] [doi: 10.1016/S1042-3699(02)00102-4]

8. Kipp DP, Goldstein BH, Weiss WW Jr. Dysesthesia after mandibular third molar surgery: a retrospective study and analysis of 1,377 surgical procedures. J Am Dent Assoc. 1980 Feb;100(2):185-922. [Medline: 6928147]

9. Wofford DT, Miller RI. Prospective study of dysesthesia following odontectomy of impacted mandibular third molars. J Oral Maxillofac Surg. 1987 Jan;45(1):15-9. [Medline: 3467032] [doi: 10.1016/0278-2391(87)90080-2]

10. Rood JP, Shehab BA. The radiological prediction of inferior alveolar nerve injury during third molar surgery. Br J Oral Maxillofac Surg. 1990 Feb;28(1):20-5. [Medline: 2322523] [doi: 10.1016/0266-4356(90)90005-6]

11. Renton T. Oral surgery: part 4. Minimising and managing nerve injuries and other complications. Br Dent J. 2013 Oct;215(8):393-9. [Medline: 24157759] [doi: 10.1038/sj.bdj.2013.993]

12. Blackburn CW, Bramley PA. Lingual nerve damage associated with the removal of lower third molars. Br Dent J. 1989 Aug 5;167(3):103-7. [Medline: 2765316] [doi: 10.1038/sj.bdj.4806922]

13. Gerlach KL, Hoffmeister B, Walz C. [Dysesthesia and anesthesia of the mandibular nerve following dental treatment]. Dtsch Zahnarztl Z. 1989 Dec;44(12):970-2. German. [Medline: 2639019]

14. Tay AB, Go WS. Effect of exposed inferior alveolar neurovascular bundle during surgical removal of impacted lower third molars. J Oral Maxillofac Surg. 2004 May;62(5):592-600. [Medline: 15122566] [doi: 10.1016/j.joms.2003.08.033]

15. Cheung LK, Leung YY, Chow LK, Wong MC, Chan EK, Fok YH. Incidence of neurosensory deficits and recovery after lower third molar surgery: a prospective clinical study of 4338 cases. Int J Oral Maxillofac Surg. 2010 Apr;39(4):320-6. [Medline: 20061121] [doi: 10.1016/j.ijom.2009.11.010]

16. Haug RH, Perrott DH, Gonzalez ML, Talwar RM. The American Association of Oral and Maxillofacial Surgeons Age-Related Third Molar Study. J Oral Maxillofac Surg. 2005 Aug;63(8):1106-14. [Medline: 16094577] [doi: 10.1016/j.joms.2005.04.022] 
17. Lopes V, Mumenya R, Feinmann C, Harris M. Third molar surgery: an audit of the indications for surgery, postoperative complaints and patient satisfaction. Br J Oral Maxillofac Surg. 1995 Feb;33(1):33-5. [Medline: 7718526] [doi: 10.1016/0266-4356(95)90083-7]

18. Chien PF, Khan KS, Siassakos D. Registration of systematic reviews: PROSPERO. BJOG. 2012 Jul;119(8):903-5. [Medline: 22703418] [doi: 10.1111/j.1471-0528.2011.03242.x]

19. Moher D, Liberati A, Tetzlaff J, Altman DG; PRISMA Group. Preferred reporting items for systematic reviews and metaanalyses: the PRISMA statement. Int J Surg. 2010;8(5):336-41. Epub 2010 Feb 18. Erratum in: Int J Surg. $2010 ; 8(8): 658$. [Medline: 20171303] [doi: 10.1016/j.ijsu.2010.02.007]

20. Higgins JPT, Green S. Cochrane Handbook for Systematic Reviews of Interventions. [URL: http://www.cochrane.org/ cochrane-interventions-handbook]

21. Smith WP. The relative risk of neurosensory deficit following removal of mandibular third molar teeth: the influence of radiography and surgical technique. Oral Surg Oral Med Oral Pathol Oral Radiol. 2013 Jan;115(1):18-24. Epub 2012 Aug 22. [Medline: 22921833] [doi: 10.1016/j.0000.2012.03.017]

22. Xu GZ, Yang C, Fan XD, Yu CQ, Cai XY, Wang Y, He D. Anatomic relationship between impacted third mandibular molar and the mandibular canal as the risk factor of inferior alveolar nerve injury. Br J Oral Maxillofac Surg. 2013 Dec;51(8):e215-9. Epub 2013 Feb 11. [Medline: 23411471] [doi: 10.1016/j.bjoms.2013.01.011]

23. Jhamb A, Dolas RS, Pandilwar PK, Mohanty S. Comparative efficacy of spiral computed tomography and orthopantomography in preoperative detection of relation of inferior alveolar neurovascular bundle to the impacted mandibular third molar. J Oral Maxillofac Surg. 2009 Jan;67(1):58-66. [Medline: 19070749] [doi: 10.1016/i.joms.2008.06.014]

24. Kim JW, Cha IH, Kim SJ, Kim MR. Which risk factors are associated with neurosensory deficits of inferior alveolar nerve after mandibular third molar extraction? J Oral Maxillofac Surg. 2012 Nov;70(11):2508-14. Epub 2012 Aug 15. [Medline: 22901857] [doi: 10.1016/j.joms.2012.06.004]

25. Bell GW. Use of dental panoramic tomographs to predict the relation between mandibular third molar teeth and the inferior alveolar nerve. Radiological and surgical findings, and clinical outcome. Br J Oral Maxillofac Surg. 2004 Feb;42(1):21-7. [Medline: 14706294] [doi: 10.1016/S0266-4356(03)00186-4]

26. de Melo Albert DG, Gomes AC, do Egito Vasconcelos BC, de Oliveira e Silva ED, Holanda GZ. Comparison of orthopantomographs and conventional tomography images for assessing the relationship between impacted lower third molars and the mandibular canal. J Oral Maxillofac Surg. 2006 Jul;64(7):1030-7. [Medline: 16781335] [doi: 10.1016/i.joms.2006.03.020]

27. Maegawa H, Sano K, Kitagawa Y, Ogasawara T, Miyauchi K, Sekine J, Inokuchi T. Preoperative assessment of the relationship between the mandibular third molar and the mandibular canal by axial computed tomography with coronal and sagittal reconstruction. Oral Surg Oral Med Oral Pathol Oral Radiol Endod. 2003 Nov;96(5):639-46. [Medline: 14600702] [doi: 10.1016/S1079-2104(03)00356-1]

28. Monaco G, Montevecchi M, Bonetti GA, Gatto MR, Checchi L. Reliability of panoramic radiography in evaluating the topographic relationship between the mandibular canal and impacted third molars. J Am Dent Assoc. 2004 Mar;135(3):3128. [Medline: 15058618$]$

29. Ohman A, Kivijärvi K, Blombäck U, Flygare L. Pre-operative radiographic evaluation of lower third molars with computed tomography. Dentomaxillofac Radiol. 2006 Jan;35(1):30-5. [Medline: 16421261] [doi: 10.1259/dmfr/58068337]

30. Ludlow JB, Davies-Ludlow LE, Brooks SL, Howerton WB. Dosimetry of 3 CBCT devices for oral and maxillofacial radiology: CB Mercuray, NewTom 3G and i-CAT. Dentomaxillofac Radiol. 2006 Jul;35(4):219-26. Erratum in: Dentomaxillofac Radiol. 2006 Sep;35(5):392. [Medline: 16798915] [doi: 10.1259/dmfr/14340323]

31. Hashimoto K, Kawashima S, Kameoka S, Akiyama Y, Honjoya T, Ejima K, Sawada K. Comparison of image validity between cone beam computed tomography for dental use and multidetector row helical computed tomography. Dentomaxillofac Radiol. 2007 Dec;36(8):465-71. [Medline: 18033942] [doi: 10.1259/dmfr/22818643]

32. Loubele M, Guerrero ME, Jacobs R, Suetens P, van Steenberghe D. A comparison of jaw dimensional and quality assessments of bone characteristics with cone-beam CT, spiral tomography, and multi-slice spiral CT. Int J Oral Maxillofac Implants. 2007 May-Jun;22(3):446-54. [Medline: 17622012]

33. Neves FS, de Almeida SM, Bóscolo FN, Haiter-Neto F, Alves MC, Crusoé-Rebello I, Campos PS. Risk assessment of inferior alveolar neurovascular bundle by multidetector computed tomography in extractions of third molars. Surg Radiol Anat. 2012 Sep;34(7):619-24. Epub 2012 Mar 15. [Medline: 22418617] [doi: 10.1007/s00276-012-0961-8]

34. Rydberg J, Liang Y, Teague SD. Fundamentals of multichannel CT. Radiol Clin North Am. 2003 May;41(3):465-74. Review. [Medline: 12797600] [doi: 10.1016/S0033-8389(03)00029-0]

35. Nakayama K, Nonoyama M, Takaki Y, Kagawa T, Yuasa K, Izumi K, Ozeki S, Ikebe T. Assessment of the relationship between impacted mandibular third molars and inferior alveolar nerve with dental 3-dimensional computed tomography. J Oral Maxillofac Surg. 2009 Dec;67(12):2587-91. [Medline: 19925976] [doi: 10.1016/j.joms.2009.07.017]

36. Hasegawa T, Ri S, Shigeta T, Akashi M, Imai Y, Kakei Y, Shibuya Y, Komori T. Risk factors associated with inferior alveolar nerve injury after extraction of the mandibular third molar--a comparative study of preoperative images by panoramic radiography and computed tomography. Int J Oral Maxillofac Surg. 2013 Jul;42(7):843-51. Epub 2013 Mar 15. [Medline: 23499150] [doi: 10.1016/j.ijom.2013.01.023] 
37. Bruce RA, Frederickson GC, Small GS. Age of patients and morbidity associated with mandibular third molar surgery. J Am Dent Assoc. 1980 Aug;101(2):240-5. [Medline: 6931159]

38. Blondeau F, Daniel NG. Extraction of impacted mandibular third molars: postoperative complications and their risk factors. J Can Dent Assoc. 2007 May;73(4):325. [Medline: 17484797]

39. Zuniga JR, Essick GK. A contemporary approach to the clinical evaluation of trigeminal nerve injuries. Oral Maxillofac Clin North Am. 1992 ;4(2):353-7.

40. Ghali GE, Epker BN. Clinical neurosensory testing: practical applications. J Oral Maxillofac Surg. 1989 Oct;47(10):10748. Review. [Medline: 2677276] [doi: 10.1016/0278-2391(89)90184-5]

41. Levant BA. Mental anaesthesia and its prognosis. Br J Oral Surg. 1967 Mar;4(3):206-12. [Medline: 5228982] [doi: 10.1016/S0007-117X(66)80038-0]

42. Akal UK, Sayan NB, Aydoğan S, Yaman Z. Evaluation of the neurosensory deficiencies of oral and maxillofacial region following surgery. Int J Oral Maxillofac Surg. 2000 Oct;29(5):331-6. [Medline: 11071233] [doi: 10.1016/S0901-5027(00)80046-6]

43. Ghaeminia H, Meijer GJ, Soehardi A, Borstlap WA, Mulder J, Bergé SJ. Position of the impacted third molar in relation to the mandibular canal. Diagnostic accuracy of cone beam computed tomography compared with panoramic radiography. Int J Oral Maxillofac Surg. 2009 Sep;38(9):964-71. Epub 2009 Jul 28. [Medline: 19640685] [doi: 10.1016/j.ijom.2009.06.007]

44. Bhat $\mathrm{P}$, Cariappa KM. Inferior alveolar nerve deficits and recovery following surgical removal of impacted mandibular third molars. J Maxillofac Oral Surg. 2012 Sep;11(3):304-8. doi: 10.1007/s12663-012-0335-0. Epub 2012 Feb 19. [Medline: 23997481] [PMC free article: 3428439] [doi: 10.1007/s12663-012-0335-0]

45. Valmaseda-Castellón E, Berini-Aytés L, Gay-Escoda C. Inferior alveolar nerve damage after lower third molar surgical extraction: a prospective study of 1117 surgical extractions. Oral Surg Oral Med Oral Pathol Oral Radiol Endod. 2001 Oct;92(4):377-83. [Medline: 11598570] [doi: 10.1067/moe.2001.118284]

46. Gülicher D, Gerlach KL. Sensory impairment of the lingual and inferior alveolar nerves following removal of impacted mandibular third molars. Int J Oral Maxillofac Surg. 2001 Aug;30(4):306-12. [Medline: 11518353] [doi: 10.1054/ijom.2001.0057]

47. Jerjes W, Upile T, Shah P, Nhembe F, Gudka D, Kafas P, McCarthy E, Abbas S, Patel S, Hamdoon Z, Abiola J, Vourvachis M, Kalkani M, Al-Khawalde M, Leeson R, Banu B, Rob J, El-Maaytah M, Hopper C. Risk factors associated with injury to the inferior alveolar and lingual nerves following third molar surgery-revisited. Oral Surg Oral Med Oral Pathol Oral Radiol Endod. 2010 Mar;109(3):335-45. Epub 2010 Jan 22. [Medline: 20097103] [doi: 10.1016/i.tripleo.2009.10.010]

48. Kjølle GK, Bjørnland T. Low risk of neurosensory dysfunction after mandibular third molar surgery in patients less than 30 years of age. A prospective study following removal of 1220 mandibular third molars. Oral Surg Oral Med Oral Pathol Oral Radiol. 2013 Oct;116(4):411-7. [Medline: 24035108] [doi: 10.1016/j.0000.2013.06.024]

49. Guerrouani A, Zeinoun T, Vervaet C, Legrand W. A Four-Year Monocentric Study of the Complications of Third Molars Extractions under General Anesthesia: About 2112 Patients. Int J ent. 2013;2013:763837. Epub 2013 Sep 11. [Medline: 24101928] [PMC free article: 3786503] [doi: 10.1155/2013/763837]

50. Landi L, Manicone PF, Piccinelli S, Raia A, Raia R. A novel surgical approach to impacted mandibular third molars to reduce the risk of paresthesia: a case series. J Oral Maxillofac Surg. 2010 May;68(5):969-74. Epub 2010 Feb 13. [Medline: 20156664] [doi: 10.1016/i.joms.2009.09.097]

51. Phillips C, Norman J, Jaskolka M, Blakey GH, Haug RH, Offenbacher S, White RP Jr. Changes over time in position and periodontal probing status of retained third molars. J Oral Maxillofac Surg. 2007 Oct;65(10):2011-7. [Medline: 17884530] [doi: 10.1016/j.joms.2006.11.055]

52. Wang Y, He D, Yang C, Wang B, Qian W. An easy way to apply orthodontic extraction for impacted lower third molar compressing to the inferior alveolar nerve. J Craniomaxillofac Surg. 2012 Apr;40(3):234-7. [Medline: 21641229] [doi: 10.1016/j.jems.2011.05.001]

53. Pogrel MA, Lee JS, Muff DF. Coronectomy: a technique to protect the inferior alveolar nerve. J Oral Maxillofac Surg. 2004 Dec;62(12):1447-52. [Medline: 15573343] [doi: 10.1016/j.joms.2004.08.003]

54. Renton T, Hankins M, Sproate C, McGurk M. A randomised controlled clinical trial to compare the incidence of injury to the inferior alveolar nerve as a result of coronectomy and removal of mandibular third molars. Br J Oral Maxillofac Surg. 2005 Feb;43(1):7-12. [Medline: 15620767] [doi: 10.1016/j.bjoms.2004.09.002]

55. Ramaraj PN. Orthodontic extraction: the riskless extraction of the impacted lower third molars close to the mandibular canal. J Oral Maxillofac Surg. 2008 Jun;66(6):1317; author reply 1317. [Medline: 18486807] [doi: 10.1016/j.joms.2008.02.008]

56. Dolanmaz D, Yildirim G, Isik K, Kucuk K, Ozturk A. A preferable technique for protecting the inferior alveolar nerve: coronectomy. J Oral Maxillofac Surg. 2009 Jun;67(6):1234-8 [Medline: 19446209] [doi: 10.1016/j.joms.2008.12.031]

57. Juodzbalys G, Wang HL, Sabalys G. Anatomy of mandibular vital structures. Part I: mandibular canal and inferior alveolar neurovascular bundle in relation with dental implantology. J Oral Maxillofac Res. 2010 Apr 1;1(1):e2. [URL: http://www.ejomr.org/JOMR/archives/2010/1/e2/e2ht.htm] [Medline: 24421958] [PMC free article: 3886040] [doi: 10.5037/jomr.2010.1102] 
58. Ramadas Y, Sealey CM. Third molar removal and nerve injury. N Z Dent J. 2001 Mar;97(427):25-8. Review. [Medline: 11355247$]$

59. Libersa P, Savignat M, Tonnel A. Neurosensory disturbances of the inferior alveolar nerve: a retrospective study of complaints in a 10-year period. J Oral Maxillofac Surg. 2007 Aug;65(8):1486-9. [Medline: 17656272] [doi: 10.1016/j.joms.2007.03.023]

60. Bui CH, Seldin EB, Dodson TB. Types, frequencies, and risk factors for complications after third molar extraction. J Oral Maxillofac Surg. 2003 Dec;61(12):1379-89. [Medline: 14663801] [doi: 10.1016/j.joms.2003.04.001]

61. Nance PE, White RP Jr, Offenbacher S, Phillips C, Blakey GH, Haug RH. Change in third molar angulation and position in young adults and follow-up periodontal pathology. J Oral Maxillofac Surg. 2006 Mar;64(3):424-8. [Medline: 16487804] [doi: 10.1016/j.joms.2005.11.012]

62. Bayram M, Ozer M, Arici S. Effects of first molar extraction on third molar angulation and eruption space. Oral Surg Oral Med Oral Pathol Oral Radiol Endod. 2009 Feb;107(2):e14-20. [Medline: 19138633] [doi: 10.1016/j.tripleo.2008.10.011]

63. Tantanapornkul W, Okouchi K, Fujiwara Y, Yamashiro M, Maruoka Y, Ohbayashi N, Kurabayashi T. A comparative study of cone-beam computed tomography and conventional panoramic radiography in assessing the topographic relationship between the mandibular canal and impacted third molars. Oral Surg Oral Med Oral Pathol Oral Radiol Endod. 2007 Feb;103(2):253-9. Epub 2006 Sep. [Medline: 17234544] [doi: 10.1016/j.tripleo.2006.06.060]

64. Blaeser BF, August MA, Donoff RB, Kaban LB, Dodson TB. Panoramic radiographic risk factors for inferior alveolar nerve injury after third molar extraction. J Oral Maxillofac Surg. 2003 Apr;61(4):417-21. [Medline: 12684956] [doi: $10.1053 /$ joms.2003.50088]

65. Gomes AC, Vasconcelos BC, Silva ED, Caldas Ade F Jr, Pita Neto IC. Sensitivity and specificity of pantomography to predict inferior alveolar nerve damage during extraction of impacted lower third molars. J Oral Maxillofac Surg. 2008 Feb;66(2):256-9. [Medline: 18201605] [doi: 10.1016/i.joms.2007.08.020]

66. Ohman A, Kivijärvi K, Blombäck U, Flygare L. Pre-operative radiographic evaluation of lower third molars with computed tomography. Dentomaxillofac Radiol. 2006 Jan;35(1):30-5. [Medline: 16421261] [doi: 10.1259/dmfr/58068337]

67. Sedaghatfar M, August MA, Dodson TB. Panoramic radiographic findings as predictors of inferior alveolar nerve exposure following third molar extraction. J Oral Maxillofac Surg. 2005 Jan;63(1):3-7. [Medline: 15635549] [doi: 10.1016/j.joms.2004.05.217]

68. Rood JP. Degrees of injury to the inferior alveolar nerve sustained during the removal of impacted mandibular third molars by the lingual split technique. Br J Oral Surg. 1983 Jun;21(2):103-16. [Medline: 6575812] [doi: $10.1016 / 0007-117 X(83) 90054-9]$

69. Haas DA, Lennon D. A 21 year retrospective study of reports of paresthesia following local anesthetic administration. J Can Dent Assoc. 1995 Apr;61(4):319-20, 323-6, 329-30. [Medline: 7736335]

70. Yekta SS, Smeets R, Stein JM, Ellrich J. Assessment of trigeminal nerve functions by quantitative sensory testing in patients and healthy volunteers. J Oral Maxillofac Surg. 2010 Oct;68(10):2437-51. doi: 10.1016/j.joms.2009.12.013. Epub 2010 Jul 3. [Medline: 20598414] [doi: 10.1016/i.joms.2009.12.013]

71. Juodzbalys G, Wang HL, Sabalys G. Injury of the Inferior Alveolar Nerve during Implant Placement: a Literature Review. J Oral Maxillofac Res. 2011 Apr 1;2(1):e11. [URL: http://www.ejomr.org/JOMR/archives/2011/1/e1/v2n1e1ht.htm] [Medline: 24421983] [PMC free article: 3886063] [doi: 10.5037/jomr.2011.2101]

72. Robinson PP. Observations on the recovery of sensation following inferioralveolar nerve injuries. Br J Oral Maxillofac Surg. 1988 Jun;26(3):177-89. [Medline: 3165015] [doi: 10.1016/0266-4356(88)90161-1]

\section{To cite this article:}

Sarikov R, Juodzbalys G. Inferior Alveolar Nerve Injury after Mandibular Third Molar Extraction: a Literature Review.

J Oral Maxillofac Res 2014;5(4):e1

URL: http://www.ejomr.org/JOMR/archives/2014/4/e1/v5n4e1ht.pdf

doi: $10.5037 /$ jomr.2014.5401

Copyright (C) Sarikov R, Juodzbalys G. Published in the JOURNAL OF ORAL \& MAXILLOFACIAL RESEARCH (http://www.ejomr.org), 29 December 2014.

This is an open-access article, first published in the JOURNAL OF ORAL \& MAXILLOFACIAL RESEARCH, distributed under the terms of the Creative Commons Attribution-Noncommercial-No Derivative Works 3.0 Unported License, which permits unrestricted non-commercial use, distribution, and reproduction in any medium, provided the original work and is properly cited. The copyright, license information and link to the original publication on (http://www.ejomr.org) must be included. 